https://doi.org/10.18485/kud_kiaz.2019.ch3

\author{
Fikrat Jahangirov \\ Azerbaijan University of Languages \\ f.jahangirov@adu.edu.az
}

\title{
MULTILINGUALISM IN AZERBAIJAN SINCE THE ANCIENT TIMES UP TO THE XX CENTURY
}

\begin{abstract}
SUMMARY
Despite the fact that different ethnoses from ancient times protected their language and traditions, the leading ethno-cultural position in the country has still belonged to Azerbaijani Turks from the Middle Ages.

As we know, in the VIII and X centuries Arabic language was the language of science, Persian language was the language of poetry and Azerbaijani language was a universal language. At the beginning of the XIX century, after the integration of northern Azerbaijan to Russia, the intellectual layer of the population was encouraged to learn Russian as well asthe Arabic and Persian languages. So, we come to the conclusion that language is a social phenomenon. If biological factors lead to the formation of language, subsequent development of language depends on social factors.
\end{abstract}

Key words: Multilingualism, culture, state, literary language, diversity.

A very important part of culture is language culture. Language and culture have not been fundamentally researched either in linguistics or in philosophical sciences (ethics, aesthetics, logic, cultural studies etc).

The geographical position of Azerbaijan, the existence of an ancient city culture here, the formation of Manna and Midia states in Azerbaijan, the long-lasting wars for the lands 
of Azerbaijan give us an idea of the genetic and typological diversity of tribes and peoples living and speaking in different languages. When investigating those historical events, it became clear that there was multilingualism in Azerbaijan since the city culture was formed in this area. Despite the fact that different ethnoses from ancient times protected their language and traditions, the leading ethno-cultural position in the country has still belonged to Azerbaijani Turks from the Middle Ages. The existence of the elements of Hun-Kipchak tribal languages, especially in the northern regions of modern Azerbaijani language confirms this. The last Turkish settlements in Azerbaijan coincide with the end of the Middle Ages.

It is clear from this that the period of being Turkish of Azerbaijani people of two stages:

The first stage - Hun-Kipchak stage

The second stage - Oguz - Seljuks stage

Mainly Hun-Kipchaks settled in the north of Azerbaijan and Oguzs settled in the south. In the III and V centuries, the Sassanis from the south occupied Azerbaijan and moved their homes to Tabriz.

With the emergence of Islam, the Sassanid dynasty was abolished. The Arab Khaliphate, spread from the Atlantic to India and China brought Arabic language together with Islam.

It is clear that from the VIII century there were a beliefs in Islam, Zoroastrianism and Christianity in Azerbaijan. Therefore, Azerbaijani, Persian and Arabic languages were the main means of communication. The expansion of trade in the cities of Azerbaijan such as Shamakhi, Ganja, Nakhchivan, Ardabil, Maragha, Tabriz strengthened the trade relations with India, Russia, Syria, Iraq, Egypt and some Asian countries. This caused the development of multilingualism in the country.

As we know, in the VIII and X centuries Arabic language was the language of science, Persian language was the language of poetry and Azerbaijani language was a universal language.

Despite, the Azerbaijani language was the universal language in the II and III centuries of A.D., the massive arrival of 
Oghuz, Seljuk and Kipchak in the XI- XII centuries resulted with the acceptance of Persian language as the official state language. During this period, classes in the madrasas were mainly conducted in Persian and Arabic languages.

The development of Turkish literary languages, including Azerbaijani literary language are related to the XIII century. There are following reasons for the development of Turkish literary language in the XIII century:

1) The existence of ancient written monuments belonging to the Turkish languages

2) The necessity of conveying Islamic traditions to the public in the Turkish languages

3) The influence of literature in Persian and Arabic languages

Nasraddin Tusi founded Maraga Observatory in 1259 and created a library with more than 400,000 copies of books. He also founded a great academy (Darul-Shafa Medicine Academy) in Tabriz, where he studied and taught various sciences. This academy which had a rich library, madrasa, observatory and hospital, played an important role in the progress of the Eastern countries' culture. Most of people who worked and studied there knew three languages fluently - Arabic, Persian and Azerbaijani. In 1501 the Safavis dynasty appeared, which formed the first central feudal state in Azerbaijan. In the same year, Shah Ismail Khatai raised the Azerbaijani language to the state language level. He created political relationships with a number of European states and wrote beautiful poetry samples in both the Persian and Azerbaijani languages. Our poet, who used these three languages in the XVI century is Mahammad Fuzuli. He was the author of many artistic and philosophical works in Azerbaijani, Persian, Arabic languages.

In the XVII century, Saib Tabrizi, Govsi Tabrizi, Mahammad Amani and others, in the XVIII century Nishat Shirvani, Shakir Shirvani, Molla Vali Vidadi, Molla Panah Vagif had indispensable roles in the development of the Azerbaijani language. 
At the beginning of the XIX century, after the integration of northern Azerbaijan to Russia, the intellectual layer of the population was encouraged to learn Russian as well asthe Arabic and Persian languages.

In the XIX century, the development of the oil industry turned Baku into a major industrial center of Russia. The national composition of the population enriched. At that time, representatives of 30 nations lived and worked in Azerbaijan.

At the beginning of the XX century, the culture of our language enriched and developed as a result of the activity of various press agencies in Russian and Azerbaijani languages in Baku, including the intellectuals who went to study in many Russian cities.

So, we come to the conclusion that language is a social phenomenon. If biological factors lead to the formation of language, subsequent development of language depends on social factors.

Only 250 languages of the more than 3000 languages are used as literary languages in the world. So, there are 250 literary languages all over the world which have their own writing. Five languages of the world have been registered as the official languages of UNO. They are: English, Russian, French, Spanish and Chinese.

There are 13 of the world's most widely spreading languages, which are also the official languages of 65 countries of the world.

After gaining independence, correspondence in all governmental structures is carried out in our native mother tongue.

So, language and writing have a specific place in the cultural system. Another important aspect of the language's relation to culture is its function of materializing and protecting its moral values. It is known that the achievement gained by many generations is later transmitted to future generations through language. But it is forgotten that human is obliged for it to language. 


\section{Literature}

Azerbijan multiculturalism. Scientific editors: acad. Kamal Abdulla, prof. E.Najafov, Baku, «BBMM», 2017

Akhundov A. Language and Culture. Baku, Yazichi, 1992.

Babayev A.. Azerbijani Language and Culture of Speech. Baku, 2009.

Mammadova S. Cultural Studies. Baku, «Kooperasiya», 2001.

Lakoff George and Mark Johnson. Metaphors We Live By. University of Chicago Press, 1980.

Sapir Edward. Selected Writings of Edward Sapir in Language, Culture, and Personality. Edited by David G. Mandelbaum. University of California Press, 1949.

Wierzbicka Anna. Semantics, Culture, and Cognition. Oxford University Press, 1992.

Williams Geoffrey and Ruqaiya Hasan. Literacy in Society. Longman, 1996.

\section{PЕЗЮМЕ}

Представители различных этносов (тюрки, иранцы, иберы, кавказцы и др.), с древних веков проживающие на территории Азербайджана, до нашего времени смогли сохранить свой язык, обычаи, традиции, но при этом, начиная со средних веков, ведущая этнокультурная роль в стране принадлежала азербайджанским тюркам.

Начиная с VIII-X веков в Азербайджане арабский становится языком науки, персидский - поэзии, а Азербайджанский - межнационального общения. После присоединения северной части Азербайджана к России интеллигенция страны наряду с арабским и персидским стала изучать и русский язык. Из сказанного явствует, что язык - общественное явление. Хотя в его появлении основное место занимают биологические факторы, последующее развитие языка связано с общественными явлениями.

Ключевые слова: многоязычие, культура, государство, литературный язык, разнообразие. 